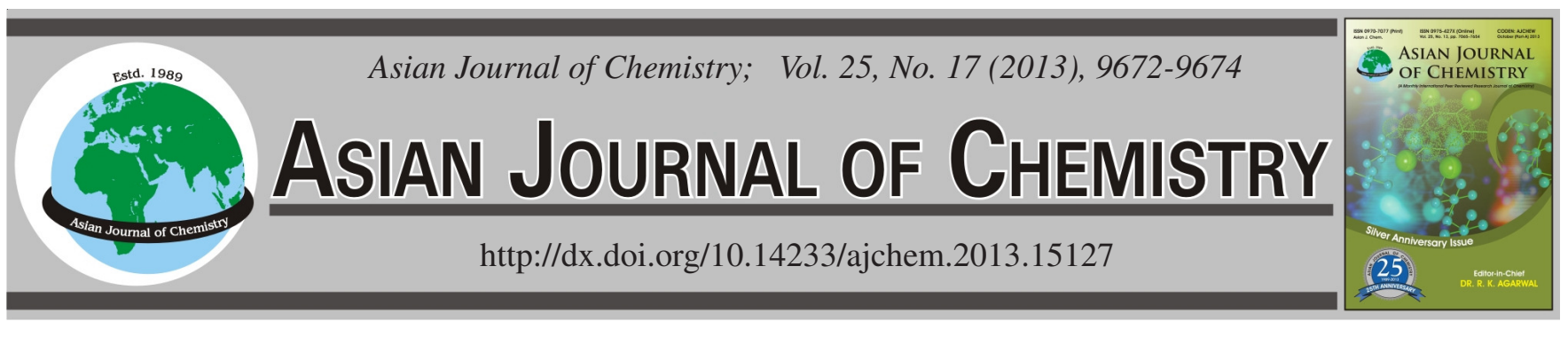

\title{
Pterocarpan Derivatives from Clinopodium urticifolium and Their Cytotoxicity
}

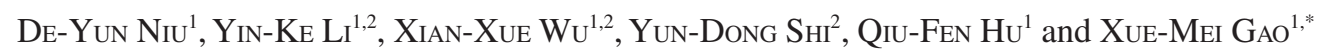

${ }^{1}$ Key Laboratory of Chemistry in Ethnic Medicinal Resources, State Ethnic Affairs Commission \& Ministry of Education, Yunnan University of Nationalities, Kunming 650031, P.R. China

${ }^{2}$ Collge of Resource and Environment, Yuxi Normal University, Yuxi 653100, P.R. China

*Corresponding author: E-mail: gao_xuemei@hotmail.com

\begin{abstract}
A new pterocarpan, 3(S),4(S)-3'-methoxy-4'-hydroxy-7,8,-methylenedioxylpterocarpan (1), together with four known pterocarpan derivatives (2-5), were isolated from the whole plant of Clinopodium urticifolium. The structure of $\mathbf{1 - 5}$ was elucidated by spectroscopic methods including extensive 1D and 2D NMR techniques. Compound $\mathbf{1}$ was also evaluated for its cytotoxicity against five human tumor cell lines. The results revealed that compound 1 showed high cytotoxicity against PC3 cell with $\mathrm{IC}_{50}$ values of $3.5 \mu \mathrm{M}$ and moderate cytotoxicities with $\mathrm{IC}_{50}$ valves $5-10 \mu \mathrm{M}$ for other four tested cell lines.
\end{abstract}

Key Words: Clinopodium urticifolium, Pterocarpan derivatives, Cytotoxicity.

\section{INTRODUCTION}

Clinopodium genus species are popular traditional Chinese medicinal herbs used to treat bruises and swelling and are also purported to improve blood circulation ${ }^{1,2}$. In recent years, several papers have described phytochemistry investigations of various species of clinopodium and it was found to be rich in saponins ${ }^{3,4}$, flavones ${ }^{5,6}$, polyphenols ${ }^{7,8}$, terpenes ${ }^{9,10}$, etc.

Clinopodium urticifolium belongs to the Clinopodium genus, which widely distributed in Gansu, shaanxi, ningxia, in northwest China. In previous work, some bioactive compounds were isolated from this plant ${ }^{8,11,12}$. Motivated by a search for bioactive metabolites from this plant, a reinvestigation for the chemical constituents of the whole plant of C. urticifolium were carried out. As a result, a new pterocarpan (1), together with four known pterocarpan derivatives (2-5), were isolated from this plant. In addition, the cytotoxicity of compound 1 was evaluated. This work deals with the isolation, structural elucidation and biological activities of the new compound.

\section{EXPERIMENTAL}

Optical rotations were measured with a Horiba SEPA-300 polarimeter. UV spectra were obtained using a Shimadzu UV2401A spectrophotometer. CD spectra were measured on a JASCO J-810 spectropolarimeter. A Tenor 27 spectrophotometer was used for scanning IR spectroscopy with $\mathrm{KBr}$ pellets. 1D and 2D NMR spectra were recorded on DRX-500 spectrometers with TMS as internal standard. Unless otherwise specified, chemical shifts $(\delta)$ were expressed in ppm with reference to the solvent signals. HRESIMS was performed on an API QSTAR time-of-flight spectrometer and a VG Autospec-3000 spectrometer, respectively. Preparative HPLC was performed on a Shimadzu LC-8A preparative liquid chromatograph with a ZORBAX PrepHT GF $(21.2 \mathrm{~mm} \times 25 \mathrm{~cm}, 7 \mu \mathrm{m})$ column or a Venusil MP $\mathrm{C}_{18}(20 \mathrm{~mm} \times 25 \mathrm{~cm}, 5 \mu \mathrm{m})$ column. Column chromatography was performed with Si gel (200-300 mesh, Qing-dao Marine Chemical, Inc., Qingdao, China), Lichroprep RP-18 gel (40-63 $\mu$ M, Merck, Darmstadt, Germany), Sephadex LH-20 (Sigma-Aldrich, Inc, USA) and MCI gel (75-150 $\mu \mathrm{M}$, Mitsubishi Chemical Corporation, Tokyo, Japan). The fractions were monitored by TLC and spots were visualized by heating Si gel plates sprayed with $5 \% \mathrm{H}_{2} \mathrm{SO}_{4}$ in $\mathrm{EtOH}$.

The whole plant of $C$. urticifolium was collected in Gansu Province, People's Republic of China, in September 2010. The identification of plant material was verified by Prof. Ning Yuan. A voucher specimen (Ynni-10-09-34) has been deposited in our Laboratory.

Extraction and isolation: The air-dried and powdered whole plant of $C$. urticifolium $(3.8 \mathrm{~kg}$ ) was extracted four times with $70 \%$ aqueous methanol $(3.0 \mathrm{~L} \times 4.5 \mathrm{~L})$ at room temperature and filtered. The crude extract (182 g) was applied to silica gel (200-300 mesh) column chromatography, eluting with a chloroform-acetone gradient system (20:1, 9:1, 8:2, 7:3, $6: 4,5: 5)$, to give six fractions A-F. The separation of fraction 
$\mathrm{C}(8: 2,14.6 \mathrm{~g})$ by silica gel column chromatography, eluted with chloroform-methanol and preparative HPLC (40\% methanol, flow rate $12 \mathrm{~mL} / \mathrm{min})$ to give $\mathbf{1}(22.8 \mathrm{mg})$ and $\mathbf{2}$ $(15.6 \mathrm{mg})$. The further separation of fraction $\mathrm{D}(7: 3,13.8 \mathrm{~g})$ by silica gel column chromatography, eluted with chloroformmethanol and preparative HPLC (36\% methanol, flow rate $12 \mathrm{~mL} / \mathrm{min})$ to give $\mathbf{3}(18.8 \mathrm{mg}), \mathbf{4}(21.5 \mathrm{mg})$ and $\mathbf{5}(26.4 \mathrm{mg})$. 3(S),4(S)-3'-Methoxy-4'-hydroxy-7,8,-methylenedioxylpterocarpan (1): Obtained as pale yellow gum; $[\alpha]_{24.8}^{\mathrm{D}}+247$ (c 0.020, MeOH); $\mathrm{CD}(\mathrm{c} 0.02, \mathrm{MeOH}), \mathrm{nm}(\Delta \varepsilon), 285$ (-3.97), 250 (+18.4), 232 (-22.8); UV (MeOH), $\lambda_{\max }(\log \varepsilon) 345$ (2.22), 296 (3.77), $210(4.28) \mathrm{nm}$; IR (KBr, $\left.v_{\max }, \mathrm{cm}^{-1}\right)$ : 3387, 2953, 2888, 1612, 1535, 1483, 1428, 1355, 1252, 1153, 1034, 862; ${ }^{1} \mathrm{H}$ and ${ }^{13} \mathrm{C}$ NMR data $\left(\mathrm{CD}_{3} \mathrm{OD}, 500\right.$ and $\left.125 \mathrm{MHz}\right)$, Table-1; ESI-MS (positive ion mode) $\mathrm{m} / \mathrm{z} 337[\mathrm{M}+\mathrm{Na}]^{+}$; HR-ESI-MS (positive ion mode) $\mathrm{m} / \mathrm{z} 337.0693[\mathrm{M}+\mathrm{Na}]^{+}$(calcd. (\%) 337.0688 for $\mathrm{C}_{17} \mathrm{H}_{14} \mathrm{NaO}_{6}$ ).

\section{RESULTS AND DISCUSSION}

The air-dried and powdered whole plant of $C$. urticifolium $(3.8 \mathrm{~kg})$ was extracted with $70 \%$ aqueous methanol $(3 \times 4.5 \mathrm{~L})$ at room temperature and filtered to yield a filtrate, which was successively evaporated under reduced pressure to obtain a crude extract (182 g). This crude extract was subjected repeatedly to column chromatography on $\mathrm{Si}$ gel, Sephadex LH-20, RP-18 and preparative HPLC to afford a new pterocarpan, 3(S),4(S)-3'-methoxy-4'-hydroxy-7,8,-methylenedioxylpterocarpan (1), together with four known pterocarpan derivatives (2-5). The structures of the compounds 1-6 were as shown in Fig. 1 and the ${ }^{1} \mathrm{H}$ and ${ }^{13} \mathrm{C}$ NMR data of the compound 1 were listed in Table-1. The known compounds, compared with literature, were identified as: (-)-pterocarpan $(2)^{13},(-)-10$-methoxymedicarpin $(3)^{14}$ medicarpin $(4)^{15}$, 3-hydroxy-9- methycoumestan $(\mathbf{5})^{13}$.
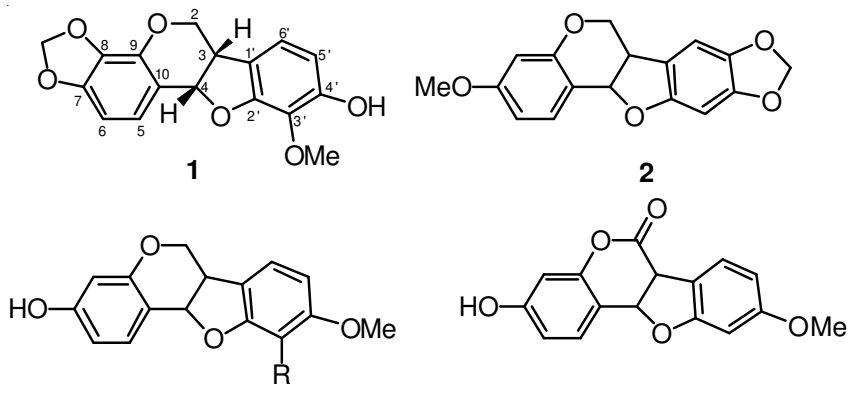

$3 \mathrm{R}=\mathrm{OMe} ; 4 \mathrm{R}=\mathrm{H}$

5
Compound 1 was obtained as a pale yellow gum with $[\alpha]_{24.8}^{\mathrm{D}_{2}}+247$ (c 0.020, MeOH). The absorption bands accounting for hydroxyl $\left(3387 \mathrm{~cm}^{-1}\right)$ and aromatic groups $(1612,1535$, $1483,1428 \mathrm{~cm}^{-1}$ ) could be observed in its IR (infrared) spectrum. The UV spectrum of $\mathbf{1}$ showed maximum absorption at 345, 296 and $210 \mathrm{~nm}$ which confirmed the existence of the aromatic functions. Its molecular formula was established by the negative mode HRESIMS (high-resolution electron spray ionization mass spectra) peak at $\mathrm{m} / \mathrm{z} 337.0693[\mathrm{M}+\mathrm{Na}]^{+}$ (calcd. (\%) 337.0688 for $\mathrm{C}_{17} \mathrm{H}_{14} \mathrm{NaO}_{6}$ ). The ${ }^{1} \mathrm{H}$ NMR spectrum suggested a pterocarpan structure due to the splitting pattern of the protons at $\delta_{\mathrm{H}} 4.31(\mathrm{dd}, J=4.6,10.5 \mathrm{~Hz}, \mathrm{H}-4 \mathrm{a}), \delta_{\mathrm{H}} 3.55$ $(\mathrm{t}, J=10.5 \mathrm{~Hz}, \mathrm{H}-2 \beta), \delta_{\mathrm{H}} 3.48(\mathrm{~m}, \mathrm{H}-3)$ and $\delta_{\mathrm{H}} 5.48(\mathrm{~d}, J=6.6$ $\mathrm{Hz}, \mathrm{H}-4)$, related to the protons of the heterocyclic ring $\mathrm{B}$. This spectrum also allowed the identification of two pairs of ortho situated aromatic protons at $\delta_{\mathrm{H}} 6.99(\mathrm{~d}, J=8.5 \mathrm{~Hz}$, H-5), $\delta_{\mathrm{H}} 6.61$ (d, J=8.5 Hz, H-6), $\delta_{\mathrm{H}} 6.54$ (d, J=8.1 Hz, H-5') and $\delta_{\mathrm{H}} 6.72\left(\mathrm{~d}, J=8.1 \mathrm{~Hz}, \mathrm{H}-6^{\prime}\right)$ and gave a clear evidence of the $7,8,3^{\prime}, 4^{\prime}$-substitution pattern of the pterocarpan moiety ${ }^{16}$. In addition, one methylenedioxy group signals $\left(\delta_{\mathrm{H}} 5.89,5.91\right.$ s) and one methoxy group signal $\left(\delta_{\mathrm{H}} 3.80\right)$ was also observed. All these data were supported by the ${ }^{13} \mathrm{C}$ and DEPT spectrum that revealed 17 carbon atoms corresponding to one methyl, two methylene, six methines and eight non-hydrogenated carbons (Table-1). However, the confirmation of the above suggestion for 1 was supported by the HSQC and HMBC (Fig. 2) experiments, which allowed the unequivocal assignments of its ${ }^{13} \mathrm{C}$ and ${ }^{1} \mathrm{H}$ NMR data. The assignments of the position of the methoxy group at C-3' was defined in the HMBC spectrum that showed cross-peaks of the methoxyl proton at $\delta_{\mathrm{H}} 3.80(-\mathrm{OMe})$ with the carbon at $\delta_{\mathrm{C}} 140.6\left(\mathrm{C}-4{ }^{\prime}\right)$. The methylenedioxy group located at C-7 and C-8 was supported by the HMBC correlations of methylenedioxyl proton at $\delta_{\mathrm{H}}$ $5.89,5.91\left(-\mathrm{OCH}_{2} \mathrm{O}-\right)$ with the carbon at $\delta_{\mathrm{C}} 146.9(\mathrm{C}-7)$ and $\delta_{\mathrm{C}} 133.4$ (C-8). Since the positions of the methoxy group and methylenedioxy group was determined, a hydroxy group should be located at C-4' to support the tetrassubstituted aromatic B-ring.

It is well known from the literature that, according to biogenetical regulations, the hydrogens ( $\mathrm{H}-3$ and $\mathrm{H}-4)$ at the $\mathrm{B} / \mathrm{C}$ rings junction of all natural pterocarpans are always cis, either $\alpha, \alpha$ or $\beta, \beta$, thus leading to only two enantiomeric forms. It is also known, through CD (circular dichroism) and/or ORD (optical rotatory dispersion) analyses, that (-) optical rotation can be associated with $\alpha, \alpha$ positioning (3R, $4 \mathrm{R})$, while the (+) optical rotation can be associated with the $\beta, \beta$-positioning

Fig. 1. Structures of pterocarpans from the C. urticifolium

TABLE-1

${ }^{1} \mathrm{H}$ NMR AND ${ }^{13} \mathrm{C}$ NMR DATA OF COMPOUND 1 (OBTAINED IN CD ${ }_{3} \mathrm{OD}$ )

\begin{tabular}{|c|c|c|c|c|c|}
\hline No. & $\delta_{\mathrm{C}}$ (mult.) & $\delta_{\mathrm{H}}($ mult $, J, \mathrm{~Hz})$ & No. & $\delta_{\mathrm{C}}$ (mult.) & $\delta_{\mathrm{H}}($ mult $, J, \mathrm{~Hz})$ \\
\hline $2 \alpha$ & $68.0 \mathrm{t}$ & $4.31, \mathrm{dd}, J=4.6,10 .$. & 10 & $114.0 \mathrm{~s}$ & - \\
\hline $2 \beta$ & $68.0 \mathrm{t}$ & $3.55, \mathrm{t}, J=10.5$ & $1^{\prime}$ & $122.9 \mathrm{~s}$ & - \\
\hline 3 & $42.0 \mathrm{~d}$ & $3.48 \mathrm{~m}$ & $2^{\prime}$ & $147.0 \mathrm{~s}$ & - \\
\hline 4 & $80.9 \mathrm{~d}$ & $5.48, \mathrm{~d}, J=6.6$ & $3^{\prime}$ & $140.6 \mathrm{~s}$ & - \\
\hline 5 & $121.9 \mathrm{~d}$ & $6.99, \mathrm{~d}, J=8.5$ & $4^{\prime}$ & $144.0 \mathrm{~s}$ & - \\
\hline 6 & $110.2 \mathrm{~d}$ & $6.61, \mathrm{~d}, J=8.5$ & $5^{\prime}$ & $106.9 \mathrm{~d}$ & $6.54, \mathrm{~d}, J=8.1$ \\
\hline 7 & $146.9 \mathrm{~s}$ & - & $6^{\prime}$ & $115.8 \mathrm{~d}$ & $6.72, \mathrm{~d}, J=8.1$ \\
\hline 8 & $133.4 \mathrm{~s}$ & - & $-\mathrm{OCH}_{2} \mathrm{O}-$ & $101.2 \mathrm{t}$ & $5.89,5.91 \mathrm{~s}$ \\
\hline 9 & $145.8 \mathrm{~s}$ & - & -OMe-3' & $61.2 \mathrm{q}$ & $3.80, \mathrm{~s}$ \\
\hline
\end{tabular}




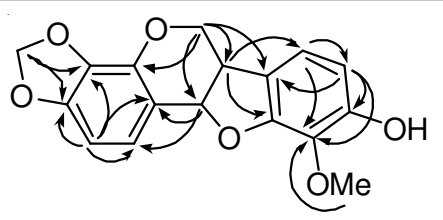

Fig. 2. Selected HMBC ( $)$ correlations of 1

$(3 \mathrm{~S}, 4 \mathrm{~S})$ of both series ${ }^{17,18}$. From the (+) optical rotation of compound 1 , it could be assumed an $(3 \mathrm{~S}, 4 \mathrm{~S})$ absolute configuration for it. As expected, the CD spectrum of $\mathbf{1}$ should a similar profile of that from (+)-pterocarpin and almost a mirror image of (-)-maackiain, what is in agreement with the suggested $(3 \mathrm{~S}, 4 \mathrm{~S})$ absolute stereochemistry for compound $\mathbf{1}$. Thus, the structure of 1 was determined as 3(S),4(S)-3'-methoxy-4'-hydroxy7,8,-methylenedioxylpterocarpan.

Since certain of the phenolic compounds exhibit potential cytotoxicity ${ }^{19-23}$, the compound $\mathbf{1}$ was tested for their cytotoxicity against five human tumor cell lines (NB4, A549, SHSY5Y, PC3 and MCF7) using the MTT method as reported previously ${ }^{24}$. Taxol was used as the positive control. The results revealed that compound $\mathbf{1}$ showed high cytotoxicity against PC3 cell with $\mathrm{IC}_{50}$ values of $3.5 \mu \mathrm{M}$ and moderate cytotoxicities with $\mathrm{IC}_{50}$ valves $5-10 \mu \mathrm{M}$ for other four tested cell lines.

\section{ACKNOWLEDGEMENTS}

This project was supported financially by the Excellent Scientific and Technological Team of Yunnan High School (2010CI08) and the Yunnan University of Nationalities Green Chemistry and Functional Materials Research for Provincial Innovation Team (2011HC008) and Open Research Fund Program of Key Laboratory of Ethnic Medicine Resource Chemistry (Yunnan University of Nationalities) (2010XY08).

\section{REFERENCES}

1. H.D. Chi and J.C. Lu, J. Shenyang Pharm. Univ., 23, 123 (2006)

2. J.L. Trusty, R.G. Olmstead, D.J. Bogler, A. Santos-Guerra and J. FranciscoOrtega, Syst. Bot., 29, 702 (2004).
3. A. Yamamoto, H. Suzuki, T. Miyase, A. Ueno and T. Maeda, Phytochemistry, 34, 485 (1993).

4. Z. Liu, D. Li, N.L. Owen, D.M. Grant, R.G. Cates and Z. Jia, J. Nat. Prod., 58, 1600 (1995).

5. Y.H. Kuo, H.M.S. Lee and J.S.H. Lai, J. Chin. Chem. Soc. (Taipei), 47, 241 (2000).

6. Y.H. Kuo, H.M.S. Lee and J.S.H. Lai, Chin. Pharm. J. (Taipei), 52, 27 (2000).

7. P. Pripdeevech and E. Chukeatirote, Food Chem. Toxicol., 48, 2754 (2010).

8. Q.F. Hu, H.X. Mu, H.T. Huang, H.Y. Lv, S.D. Li and G.Y. Yang, Chem. Nat. Compd., 48, 198 (2012).

9. X.M. Wei, J.K. Cheng, D.L. Cheng and L.M. Gao, J. Chin. Chem. Soc. (Taipei), 51, 1043 (2004).

10. F. Mori, T. Miyase and A. Ueno, Phytochemistry, 36, 1485 (1994).

11. S.H.M. Lee, J.S.H. Lai and Y.H. Kuo, J. Chin. Chem. Soc. (Taipei), 40, 87 (1993).

12. L.M. Gao, X.M. Wei and D.L. Cheng, Chin. Chem. Lett., 14, 1041 (2003).

13. D.Q. Yu and J.S. Yang, Handbook of Analytical Chemistry, Nuclear Magnetic Resonance spectroscopy, Chemical Industry Press, Beijing, edn 2, vol. 7, p. 323 (1999).

14. G.F. Spencer, B.E. Jones, R.D. Plattner, D.E. Barnekow, L.S. Brinen and J. Clardy, Phytochemistry, 30, 4147 (1991).

15. A.A. Chalmers, G.J.H. Rall and M.E. Oberholzer, Tetrahedron, 33, 1735 (1977).

16. X.Y. Zeng, W. Zhao, T. Zhang, L. Wang, G.Y. Yang, Y.K. Chen, Q.F. Hu and M.M. Miao, Phytochem. Lett., 5, 238 (2013).

17. P.A. Veloso, A.T.A. Pimenta, S. Francisco M. de, M.J.C. Falcão, N.V. Gramosa, J.N. Silva Junior, E.R. Silveira and M.A.S. Lima, J. Braz. Chem. Soc., 23, 1239 (2012).

18. T. Miyase, A. Ohtsubo, A. Ueno, T. Noro, M. Kuroyanagi and S. Fukushima, Chem. Pharm. Bull. (Tokyo), 30, 1986 (1982).

19. Y.L. Lu, X.S. Li, H.X. Mu, H.T. Huang, G.P. Li and Q.F. Hu, J. Braz. Chem. Soc., 23, 656 (2012).

20. Y. Zhang, Q. Hu, X. Gao, L. Yang, L. Shu and Y. Shen, Heterocycles, 85, 1925 (2012).

21. Q.F. Hu, X.S. Li, H.T. Huang, H.X. Mu, P.F. Tu and G.P. Li, Helv. Chim. Acta, 95, 349 (2012).

22. Q.-F. Hu, H.-X. Mu, H.-T. Huang, H.-Y. Lv, S.-L. Li, P.-F. Tu and G.-P. Li, Chem. Pharm. Bull. (Tokyo), 59, 1421 (2011).

23. D.R. Mou, W. Zhao, T. Zhang, W. Liu, G.Y. Yang, Y.K. Chen, Q.F. Hu and M.M. Miao, Asian J. Chem., 25, 6983 (2013).

24. T. Mosmann, J. Immunol. Methods, 65, 55 (1983). 